\title{
Voltammetric Study of Organic Matter Components in the Upper Reach of the Krka River, Croatia
}

\author{
Slađana Strmečki, ${ }^{1, *}$ Irena Ciglenečki, ${ }^{1}$ Marija Gligora Udovič, ${ }^{2}$ Marija Marguš, ${ }^{1}$ \\ Elvira Bura-Nakić, ${ }^{1}$ Jelena Dautović, ${ }^{1}$ Marta Plavšić ${ }^{1}$
}

\footnotetext{
1 Ruđer Bošković Institute, Division for Marine and Environmental Research, Bijenička c. 54, HR-10000 Zagreb, Croatia

2 University of Zagreb, Faculty of Science, Department of Biology, Rooseveltov trg 6, HR-10000 Zagreb, Croatia

* Corresponding author's e-mail address: strmecki@irb.hr
}

RECEIVED: November 12, 2018 * REVISED: January 8, $2019 \star$ ACCEPTED: January 12, 2019

\begin{abstract}
The increased amount of organic matter (OM) accompanied with the development of hypoxia/anoxia and appearance of the sulphur species are indicators of eutrophication in natural waters. To predict biogeochemical and ecological changes, specific OM components in the Lake Brljan (the karst Krka River, Croatia; station B and station B2 downstream) were studied during 2011 and in January 2012 using voltammetry. Surface-active substances (eq. 0.018 to $0.150 \mathrm{mg} \mathrm{dm}^{-3}$ Triton-X-100) and Cu complexing capacity $\left(54-680 \mathrm{nmol} \mathrm{dm}^{-3}\right.$ ) showed the highest values in surface water layer in May 2011 (B) and in November 2011 (B2), associated with the highest dissolved $\left(0.505-1.530 \mathrm{mg} \mathrm{C} \mathrm{dm}^{-3}\right)$ and particulate $\left(0.051-0.725 \mathrm{mg} \mathrm{C} \mathrm{dm}^{-3}\right)$ organic carbon and phytoplankton biomass. Autochthonously produced OM did not cause hypoxia/anoxia during the investigated period. Brljan's lake water could be characterised as oligotrophic with occasionally elevated OM concentration depending on season and Krka River water regime.
\end{abstract}

Keywords: Lake Brljan, Krka River, organic matter, voltammetry, phytoplankton production, oligotrophy.

\section{INTRODUCTION}

S MALL lakes as isolated water systems are ideal natural laboratories for exploring biogeochemical processes. Due to their relatively small surface and volume, they react rapidly to external pressures, so the biogeochemical signal of such reaction is multiplied with respect to the open sea and the ocean. Eutrophication is the important topic regarding the European lakes. ${ }^{[1]}$ Natural eutrophication leads to the increased primary production due to the available nutrients and suitable environmental conditions (water temperature, light availability). This mechanism causes lakes to gradually age and become more productive. If the process of natural eutrophication is enhanced by the input of the nutrients from the anthropogenic sources (untreated sewage water, surface runoff from the agricultural land...), primary production could be enhanced. ${ }^{[2]}$ Consequently, the increased concentration of organic matter (OM) could impact the water quality, especially in the systems such as lakes where the water exchange is limited. Increased amount of the OM at the lakes bottom and at edges that is available for degradation could lead to the development of hypoxic, anoxic and even euxinic conditions. A decrease of the dissolved oxygen concentration and appearance of toxic free hydrogen sulphide are the indicators of eutrophication processes in lakes. ${ }^{[3]}$ Oxygen deficiency is also associated with excessive oxygen consumption during the oxidation of freshly produced OM.[4] Therefore, better understanding of biogeochemical processes in lakes would help to predict the ecological changes and to judge their economic value. ${ }^{[5]}$

Primary OM in natural waters is a source of food for heterotrophic organisms. OM is important component in the biogeochemical cycling of carbon and one of the indicator of climate change mostly associated with the increasing $\mathrm{CO}_{2}$ concentration. ${ }^{[6]} \mathrm{OM}$ has an important influence on metal speciation, ${ }^{[7-9]}$ it is a precursor in the process of fossil fuels creation, and today $\mathrm{OM}$ is being examined as a dynamic component of the global carbon cycle. ${ }^{[10]}$ Testing and quantifying the specific components of OM such as

(c) $\mathbf{B Y}$ This work is licensed under a Creative Commons Attribution 4.0 International License. 
surface-active substances (SAS), ${ }^{[11,12]}$ organic ligands that complex metal ions (metal complexing capacity, MCC), ${ }^{7,13]}$ and/or sulphur species ${ }^{[14]}$ allows understanding of its properties and the cycle in natural waters. SAS, MCC, and sulphur species are important parameters in water quality monitoring that are usually measured by electroanalytical methods which are shown to be fast, non-destructive and relatively cheap. ${ }^{[15]}$ Furthermore, general information on $\mathrm{OM}$ in natural waters could be obtained by measuring the carbon fraction concentration in a mixture of organic compounds distributed within dissolved (dissolved organic carbon, DOC) and particulate (particulate organic carbon, POC) carbon fraction.

The aim of our study was to investigate the seasonal variability of the $\mathrm{OM}$ in respect to the changes in the concentration and properties of OM components and fractions present in the upper reach of the Krka River; in the Lake Brljan and in the downstream waters as a part of the highly protected area - the Krka National Park (Figure 1). The possible degradation of the water quality at these sites might impact the biogeochemistry in the lower reach of the Krka River such as the Lake Visovac that is also part of the Krka National Park and the salt-wedge and highly stratified estuary protected as the significant landscape. As karst areas, they are very sensitive to any external pressure like wastewaters (from Knin town) and rainfall and surface runoff (containing chemicals from agriculture). Additionally, phytoplankton biomass and species composition was

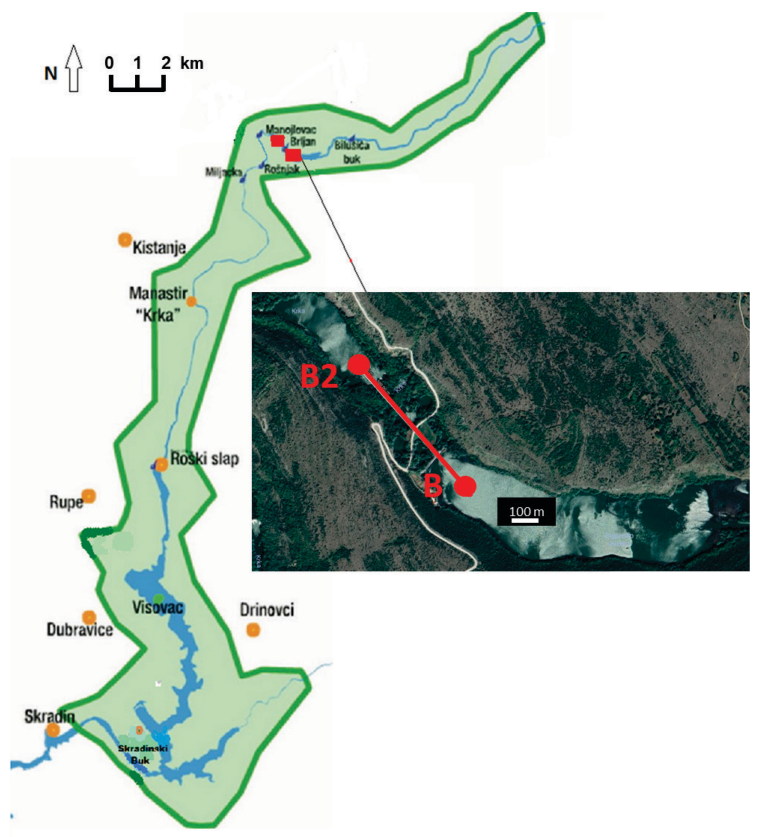

Figure 1. The Krka National Park and the Krka River with sampling stations marked B (the Lake Brljan) and B2 (the downstream waters). studied and basic physico-chemical parameters (temperature, electrical conductivity, $\mathrm{pH}$, dissolved oxygen) were measured. Alongside with the seasonal conditions, we were interesting if the Miljacka hydroelectric power plant (HPP) activities (particularly the Brljan dam) have influence on the biogeochemical processes of OM. It has been found out that HPP alters plankton distribution and its productivity in perialpine lakes. ${ }^{[16]}$ Therefore, the water column of the Lake Brljan and the downstream waters was examined considering: the content and the type of $\mathrm{OM}$ with respect to the surface activity, the capacity of organic compounds to bind $\mathrm{Cu}$ ions ( $\mathrm{Cu}$ complexing capacity, CuCC, as $\geq 99 \%$ of $\mathrm{Cu}$ in natural waters could be present in a complex with organic compounds), ${ }^{[17]}$ and the content of reduced sulphur species (RSS) by electrochemical voltammetric methods. The content of DOC and POC was determined by hightemperature catalytic oxidation (HTCO) method. Implemented research should contribute to a better understanding of the Krka River system and it might be used in the future control as well as in prevention of the processes that could lead to eventual eutrophication in the area.

\section{EXPERIMENTAL}

Sampling in the water column of the Lake Brljan (Bjelober, Ćorić) and the downstream waters was done seasonally at two selected locations (stations B and B2, respectively, Figure 1) with Niskin sampler. The Lake Brljan is a $1.3 \mathrm{~km}$ long and $0.4 \mathrm{~km}$ wide waterbody located in the upper reach of the Krka River (discharging in the Adriatic Sea), about 15 $\mathrm{km}$ southwest from the Knin town (Figure 1). The lake emerged, in part, from the growth of the travertine barriers at the Brljan barrier, but major impact on the morphology of the Lake Brljan had the construction of the concrete dam for the HPP "Miljacka". Miljacka is the largest HPP on the Krka River constructed in period 1904-1907.

SAS were determined by the electrochemical method of alternating current voltammetry (ACV) with out-of-phase mode using a BAS100A potentiostat/galvanostat (EcoChemie, Utrecht, Netherlands) connected with 663 VA Stand three-electrode system (Metrohm, Herisau, Switzerland) and interface for mercury electrode (IME). A static mercury drop electrode (SMDE, surface area $0.52 \mathrm{~mm}^{2}$ ) was the working electrode, $\mathrm{Ag} / \mathrm{AgCl}$ ( $3 \mathrm{M} \mathrm{KCl}$ ) the reference electrode and a Pt wire the counter electrode. ACV is based on the SAS adsorption effects at $0.6 \mathrm{~V}$ (vs. $\mathrm{Ag} / \mathrm{AgCl})$ on the hydrophobic surface of the SMDE. ${ }^{[8]}$ The measurements were performed at air under following conditions: accumulation potential $E_{\mathrm{a}}-0.6 \mathrm{~V}$, accumulation time $t_{\mathrm{a}} 30 \mathrm{~s}$, frequency $f 75 \mathrm{~Hz}$, amplitude $a$ $10 \mathrm{mV}$ and phase angle $90^{\circ}$. The concentration of SAS in each sample was expressed in equivalents $\left(\mathrm{mg} \mathrm{dm}^{-3}\right)$ of a model surfactant Triton-X-100. 
The copper complexing capacity (CuCC) was determined by the differential pulse anodic stripping voltammetry (DPASV) at the $\mu$ Autolab potentiostat/galvanostat type III (EcoChemie, Utrecht, Netherlands) and the same electrode system and interface as SAS. Measurement conditions were: $E_{\mathrm{a}}-0.6 \mathrm{~V}, t_{\mathrm{a}} 60 \mathrm{~s}, E_{\mathrm{s}} 10 \mathrm{mV}, a 25 \mathrm{mV}$, modulation time $0.05 \mathrm{~s}$, and interval time $0.61 \mathrm{~s}$. Pure nitrogen was passing for $300 \mathrm{~s}$ through the solution prior each measurement. The CuCC is determined by direct titration of the sample with copper ions (by adding a standard solution of $\left(\mathrm{Cu}\left(\mathrm{NO}_{3}\right)_{2}\right)$, first in the sample aliquot of natural $\mathrm{pH}$ and then in the acidified $\left(\mathrm{pH} 2\right.$ with addition of suprapur ${ }^{\circledast}$ concentrated $\mathrm{HNO}_{3}$, Merck, Darmstadt, Germany) and 24 hours UV irradiated (150 W mercury lamp, Hanau, Germany) sample aliquot. By linearization of the obtained values ( $\mathrm{Cu}_{\text {measured }} /\left(\mathrm{C} \mathrm{u}_{\mathrm{T}}-\mathrm{C} \mathrm{u}_{\text {measured }}\right)$ vs. $\left.\mathrm{C} \mathrm{u}_{\text {measured }}\right)$, the amount of the total organic ligand (CuCC) was calculated from the slope and the apparent stability constant $\left(K_{\text {app }}\right)$ of the complex from the $y$-axis intercept. ${ }^{[9]}$ DPASV enabled detection only of the labile $\mathrm{Cu}$ fraction (hydrated $\mathrm{Cu}^{2+}$ and/or $\mathrm{Cu}^{2+}$ bound with inorganic or organic ligands forming labile complexes) while on the other hand, inert $\mathrm{Cu}$-ligand complexes would not dissociate and would not be reduced at the chosen $E_{\mathrm{a}}{ }^{\left[{ }^{[15]}\right.}$ After reduction of labile $\mathrm{Cu}$ and formation of amalgam with $\mathrm{Hg}$ electrode, the stripping toward less negative potentials results in detection of reoxidation peak of $\mathrm{Cu}$ at around $-0.2 \mathrm{~V}$. The relative standard deviation (RSD) of the mean value calculated for five independent measurements was below $10 \%$. The CuCC may serve as an additional water quality assessment parameter. The higher CuCC value means that it is possible to bind higher concentration of $\mathrm{Cu}$ ions and thereby alter their bioavailability and toxicity. However, too high CuCC could indicate high load of $\mathrm{OM}$ and/or particles in the system, which then adversely affect water quality.

The presence of reduced sulphur species (RSS) was measured by linear sweep voltammetry (LSV) at the same electrochemical instrument and electrodes as SAS. RSS detection relies on the reduction process of $\mathrm{HgS}$ at around $-0.6 \mathrm{~V}$ which is deposited on the $\mathrm{Hg}$ surface at potential $E_{\mathrm{a}}$ $-0.2 \mathrm{~V}$ (vs. $\mathrm{Ag} / \mathrm{AgCl}$ ), as described previously. ${ }^{[18,19]} \mathrm{HgS}$ deposit is directly proportional to the concentration of RSS in the solution. An acidification step by passing $\mathrm{N}_{2}$ through the acidified sample is used to separate the volatile (sulphide) from non-volatile sulphur species (elemental sulphur and organo-sulphur compounds). The occurrence of sulphur species that are toxic to sea- and freshwater organisms is mainly related to the occurrence of hypoxic/anoxic conditions as a direct consequence of eutrophication processes.

For DOC and POC quantification, the lake water samples were kept in the dark glass bottles and then filtered through the $0.7 \mu \mathrm{m}$ pore size Whatman GF/F fibre filters which were previously precombusted for $4 \mathrm{~h}$ at $450^{\circ} \mathrm{C}$. All filtrates were collected in triplicate, $\mathrm{HgCl}_{2}\left(10 \mathrm{mg} \mathrm{dm}^{-3}\right)$ was added to each of them to preserve OM and they were further used for DOC analysis. Filters were stored in a liquid nitrogen $\left(-80^{\circ} \mathrm{C}\right)$ until POC analysis. DOC was determined by the high-temperature catalytic oxidation (HTCO) method at a TOC- $\mathrm{V}_{\mathrm{CPH}}$ instrument (Shimadzu, Japan). The DOC measurement was performed by direct injection of the sample into a combustion furnace at a temperature of $680^{\circ} \mathrm{C}$ through a sensitive $\mathrm{Pt} /$ silica catalyst. Organic carbon from the sample generated $\mathrm{CO}_{2}$ that was directly measured using a non-dispersed infrared (NDIR) detector. Prior to the oxidation, the inorganic carbon was removed from the sample by acidification with $\mathrm{HCl}(\sim 2 \%)$ to $\mathrm{pH} 2-3$ and evaporation of the resulting $\mathrm{CO}_{2}$ in the stream of pure air for 10 minutes. System calibration was performed with potassium hydrogen phthalate. POC was determined in filters with the week's calibration using glucose, as well as the daily check of the purity and efficiency of the system. A solid sample module SSM-5000A with TOC- $\mathrm{V}_{\mathrm{CPH}}$ carbon analyser was used. Inorganic carbon was removed from samples prior to POC measurement by adding $2 \mathrm{~mol} \mathrm{dm}^{-3}$ $\mathrm{HCl}$. Oxidation of organic carbon in the flow of pure oxygen at $900{ }^{\circ} \mathrm{C}$ produced $\mathrm{CO}_{2}$ that was detected using NDIR detector. The quantification limit was $0.228 \mathrm{mg} \mathrm{dm}^{-3}$ for DOC and $7.11 \mu \mathrm{g} \mathrm{dm}{ }^{-3}$ for POC. The precision of DOC and POC measurements, given as the RSD was based on the analysis of selected samples and the reference materials; RSD never exceeded $6 \%$ and $5 \%$, respectively. Both measurement procedures were validated trough the international intercalibrations as a prerequisite for accreditation achieved in 2017 (HRN EN ISO/IEC 17025:2007).

Water samples for phytoplankton analysis (abundance, biomass and composition) were collected at the surface, $2 \mathrm{~m}, 5 \mathrm{~m}, 8 \mathrm{~m}$ and bottom at station $B$ and at the surface, $2 \mathrm{~m}, 4 \mathrm{~m}$ and bottom at station $\mathrm{B} 2$, using the $5 \mathrm{dm}^{3}$ water sampler. The samples were preserved in $4 \%$ formaldehyde (final concentration), stored at $4{ }^{\circ} \mathrm{C}$ and analysed according to the EU Water Framework Directive (WFD) EN 15204:2006. The Utermöhl method ${ }^{[20]}$ was followed for preparing the counting chambers and $50 \mathrm{~cm}^{3}$ of subsamples were settled for at least 24 hours. Phytoplankton was counted using the inverted microscopes at $400 \mathrm{x}$ or $1000 \mathrm{x}$ magnification. The units were counted following Lund et al. ${ }^{[21]}$ For each specie biovolume was calculated after cells measurement using AxioVision software and final biomass was calculated according to Rott. ${ }^{[22]}$

Measurements of physical-chemical parameters such as temperature $T$, electrical conductivity $\sigma$, oxygen content and $\mathrm{pH}$ were made in situ with the HQ40d Portable Meter (Hach Lange, Germany). The relative accuracy for $T$ determination was $\pm 0.3{ }^{\circ} \mathrm{C}$, for $\mathrm{pH} \pm 0.002$, for $\sigma \pm 0.5 \%$ and for oxygen content $\pm 1 \%$. 


\section{RESULTS AND DISCUSSION}

\section{Hydrography}

The hydrographic characteristics of the Lake Brljan water column (station B) and the downstream waters (station B2) during 2011 and in January 2012 are shown in Figure 2. The surface water temperature at the station $B$ varied from 7 to $21^{\circ} \mathrm{C}$ during the year, while in the bottom layer it was from 6 to $18{ }^{\circ} \mathrm{C}$ (Figure 2A). At the station B2 the temperature varied between $5{ }^{\circ} \mathrm{C}$ in January 2012 and $23^{\circ} \mathrm{C}$ in September 2011 (Figure 2D). The water column was characterised by a slight thermocline near the surface during the summer at the station B (around $10 \mathrm{~m}$ depth), while station B2 (6 m depth) was exposed to a mixing of the water column. The electrical conductivity at B and B2 ranged from 347 to 795 $\mu \mathrm{S} \mathrm{cm}{ }^{-1}$, having the lowest values in March and June 2011 (Figure 2B, E). The water column of station B showed different conductivity in the surface and the bottom layer where conductivity values were generally higher (Figure 2B), while conductivity did not change significantly with depth at the station B2 (Figure 2E). The highest values were recorded in the bottom water layer of the station B in November 2011.
Higher conductivity values were recorded in winter when usually the highest water level is observed. [23] The water from the Lake Brljan belongs to the $\mathrm{Ca}-\mathrm{HCO}_{3} \mathrm{SO}_{4}{ }^{2-}$ hydrochemical type where ionic distribution is partially controlled by the Kosovčica River (the Krka's confluent) that is rich in sulphates. ${ }^{[24]}$ The $\mathrm{pH}$ values of both lake waters ranged from 7.45 to 8.33 , which is typical for the karstic Lake Brljan. ${ }^{[24]}$ Due to the oxygen concentrations 8.5-13.0 $\mathrm{mg} \mathrm{O}_{2} \mathrm{dm}^{-3}$, the saturation with dissolved oxygen was 100 $110 \%$. The lowest oxygen saturation was $80 \%$ detected in November 2011 (Figure 2C, F), indicating the highest concentration of $\mathrm{OM}$ available for degradation. In general, both sites could be mapped as well oxygenated waters through the all investigated seasons.

\section{Organic Matter and Reduced Sulphur Species}

Voltammetrically analysed SAS values were in the range from 0.018 to $0.150 \mathrm{mg} \mathrm{dm}{ }^{-3}$ of Triton-X-100 equivalent. The highest values were mostly recorded in the surface waters at both locations (not shown). 10-20\% lower values were obtained in the filtered samples (fraction that passed through $0.7 \mu \mathrm{m}$ filter pores) indicating that
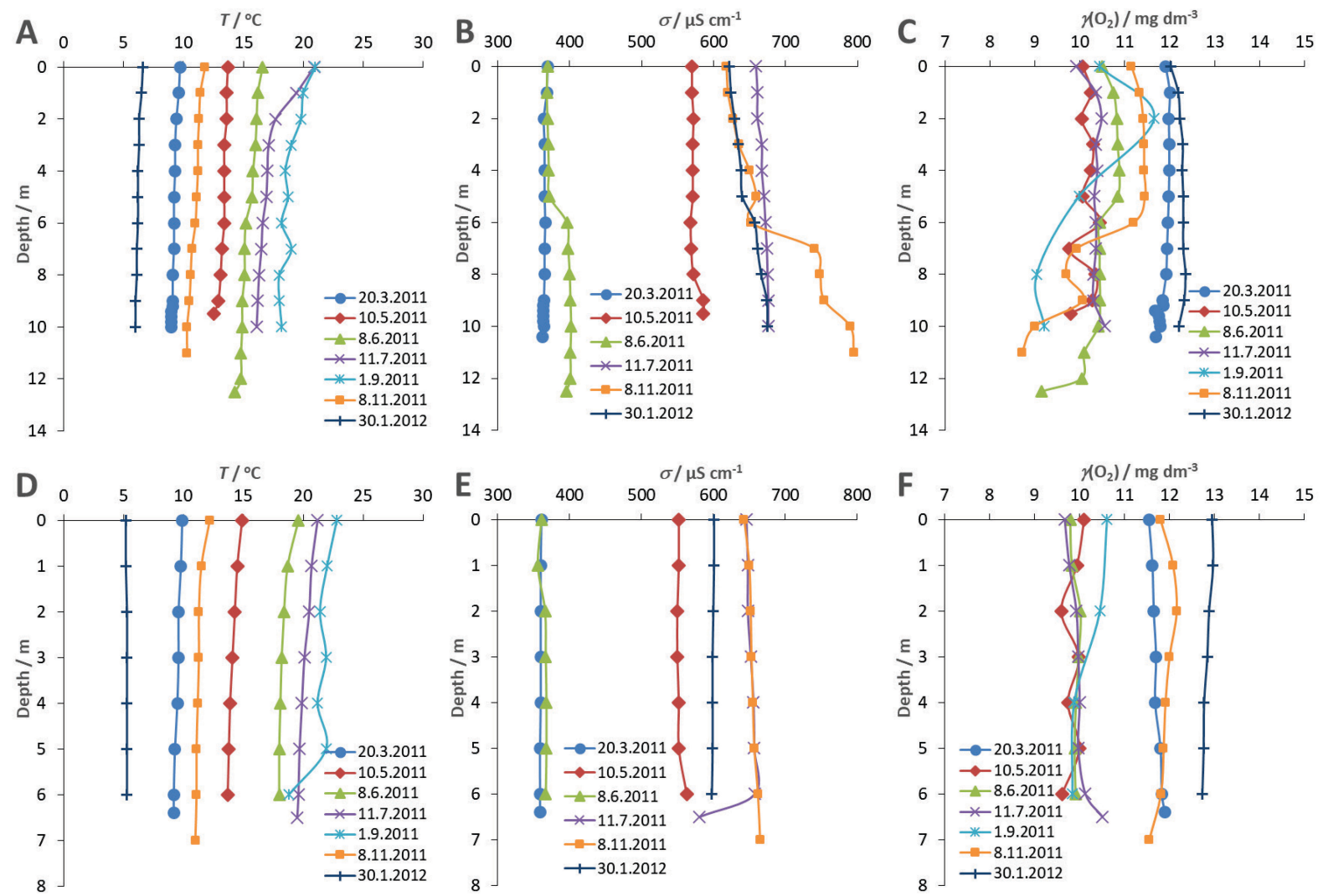

Figure 2. Hydrographic conditions: temperature $T(A, D)$, electrical conductivity $\sigma(B, E)$ and oxygen concentration $(C, F)$ in the Lake Brljan (A, B, C) and in the downstream waters (D, E, F) in 2011 and in January 2012. 
particulate organics contributed to a lesser extent to the overall surface activity. SAS concentrations were in the range of the SAS values measured in 2008 in the Krka River estuary. ${ }^{[25]}$ Concerning the SAS type, OM in the Lake Brljan and the downstream waters had poor surface activity when measured at hydrophobic no-charge bearing (at $-0.6 \mathrm{~V} v$ s. $\mathrm{Ag} / \mathrm{AgCl}$ ) working electrode, suggesting highly hydrophilic SAS character.

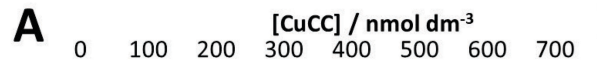

$B \quad[\mathrm{CuCC}] / \mathrm{nmol} \mathrm{dm}^{-3}$
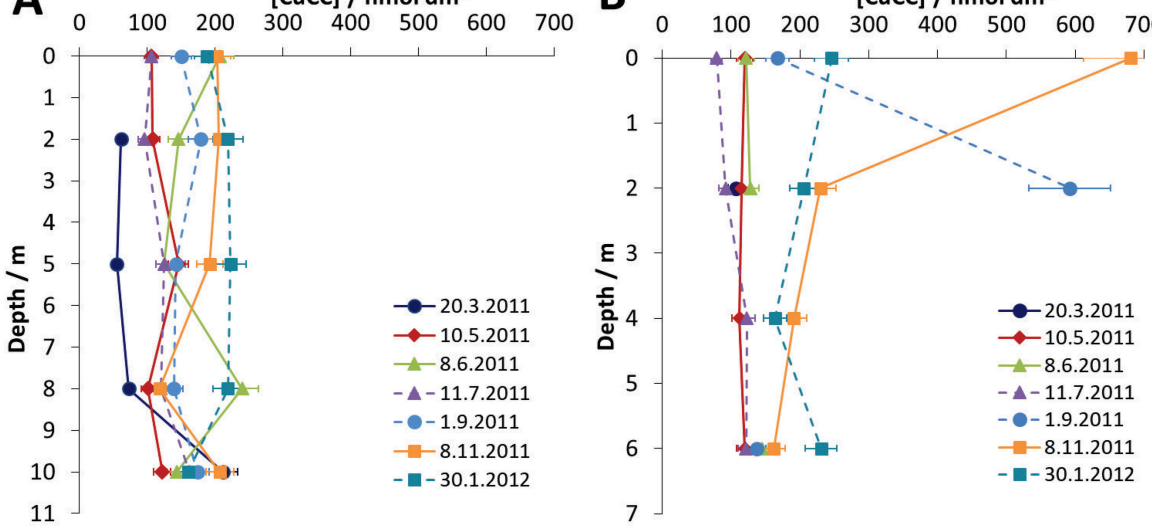

Figure 3. The CuCC values in the water column of the Lake Brljan (A) and in the downstream waters (B) in 2011 and in January 2012.
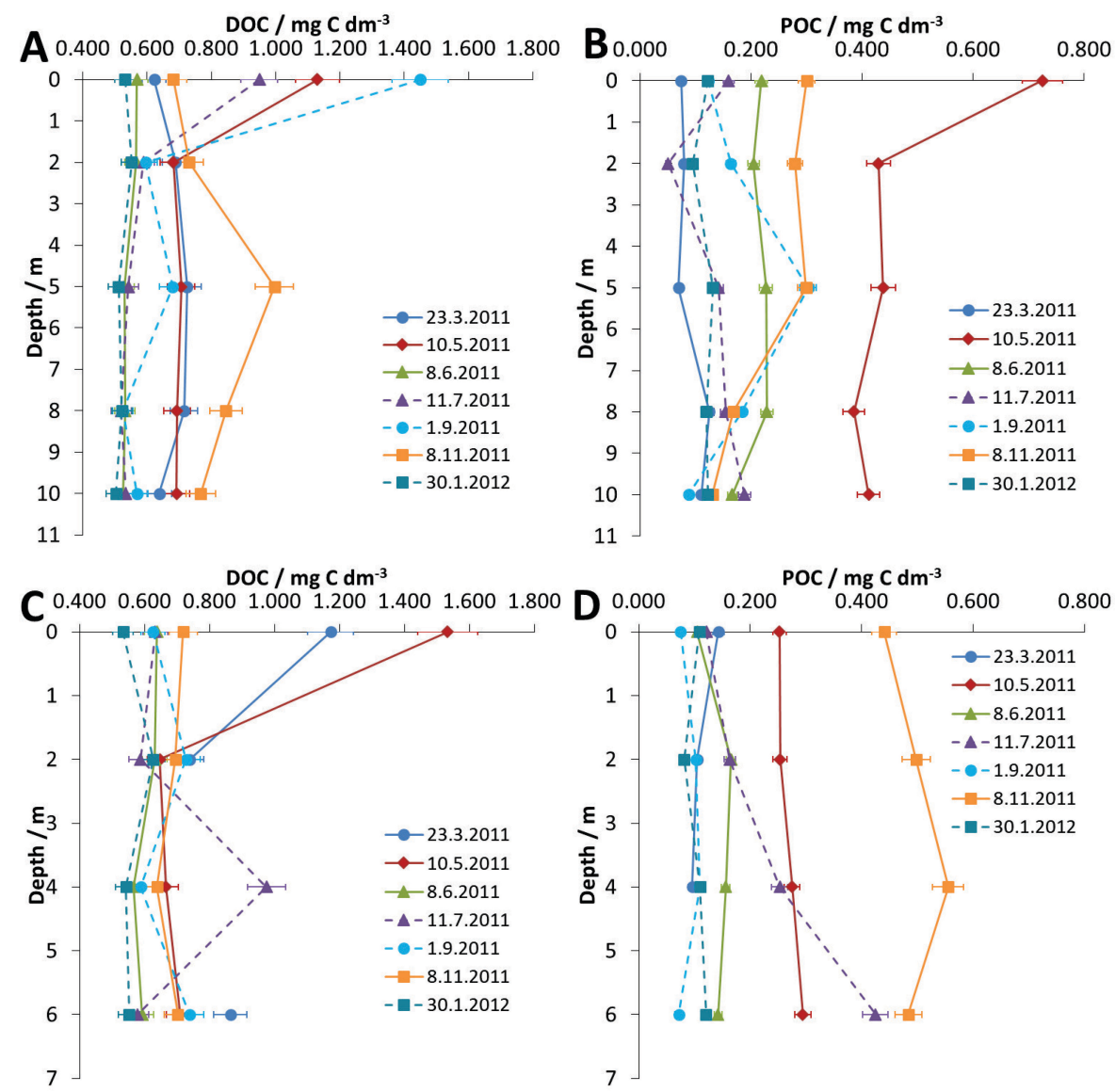

Figure 4. The distribution of $D O C(A, C)$ and $P O C(B, D)$ values in the water column of the Lake Brljan $(A, B)$ and in the downstream waters (C, D) in 2011 and in January 2012. 
Most of the CuCC values calculated for the Lake Brljan and the downstream waters showed relatively low values (54-246 nmol dm${ }^{-3}$ ) (Figure 3) that could be compared with the CuCC data obtained for the Krka River estuary in 1983, 1984 and in the period 2007-2009. ${ }^{[7,25]}$ During all seasons, the CuCC values did not change significantly in the water column of the station B (Figure $3 \mathrm{~A}$ ). Slightly increased CuCC at the bottom might indicate the contribution of particles from the sediment to the $\mathrm{CuCC}$ value since all the samples were measured unfiltered. The exception from the relatively low $\mathrm{CuCC}$ values at the station B2 is the surface sample from November 2011 when CuCC was 680 $\mathrm{nmol} \mathrm{dm}{ }^{-3}$ (Figure 3B). In the same sample, elevated POC values were observed (Figure 4D) that could imply contribution of particles in Cu binding/adsorption. SAS concentrations were also higher in November 2011 at the station B2 that may suggest increased phytoplankton abundance. The apparent stability constants of $\mathrm{Cu}-\mathrm{L}$ complexes were in the range $\log K_{\mathrm{app}}=7.6-9.7$. These values are comparable with the log $K_{\text {app }}$ previously obtained in the freshwater layer of the Krka River estuary. ${ }^{[7,25]}$

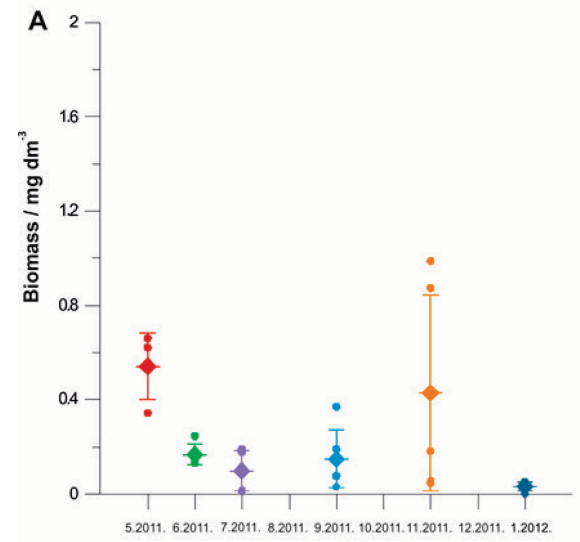

RSS, mostly of non-volatile type (organo-sulphur compounds) in the Lake Brljan and the downstream waters were detected at very low concentrations $0-5.5 \mathrm{nmol} \mathrm{dm}^{-3}$, close to the detection limit. The elevated concentrations of RSS were not recorded according to the registered hydrographic conditions (oxygen concentration). The measured RSS concentrations did not show any dependence on phytoplankton biomass at the station B in May 2011, or in November 2011 at the station B2.

The distribution of DOC and POC values $\left(\mathrm{mg} \mathrm{C} \mathrm{dm}^{-3}\right)$ within stations $B$ and $B 2$ is shown in Figure 4 . DOC values ranged from $0.505 \mathrm{mg} \mathrm{dm}^{-3}$ in the bottom waters to $1.530 \mathrm{mg} \mathrm{dm}^{-3}$ in the surface waters, with $80 \%$ of values being below $0.800 \mathrm{mg} \mathrm{C} \mathrm{dm}^{-3}$. High DOC values were measured only for surface water at the station B2 in March and May 2011 (1.173 to $1.530 \mathrm{mg} \mathrm{C} \mathrm{dm}^{-3}$, respectively) and at the station B in May and September 2011 (1.130 and $1.450 \mathrm{mg} \mathrm{C} \mathrm{dm}^{-3}$, respectively). POC concentrations ranged from 0.051 to $0.725 \mathrm{mg} \mathrm{C} \mathrm{dm}{ }^{-3}$, with the maximum determined in the surface layer at the station $B$ in May 2011. Higher concentrations of POC $\left(>0.400 \mathrm{mg} \mathrm{C} \mathrm{dm}^{-3}\right)$

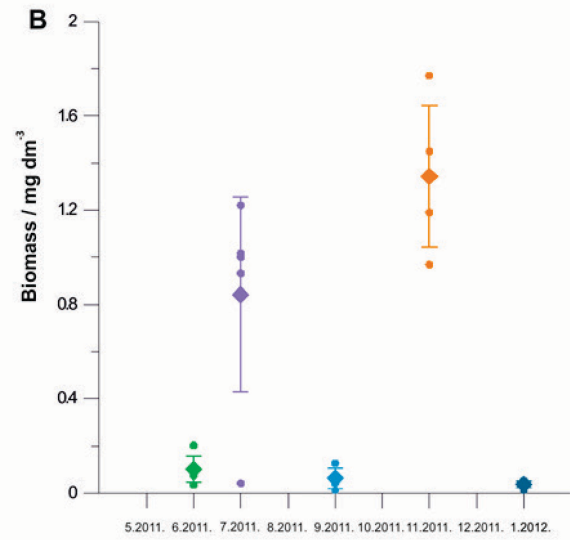

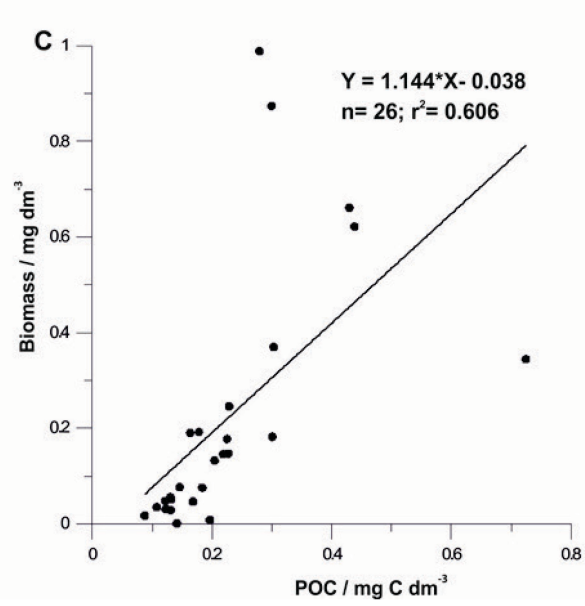

Figure 5. The phytoplankton biomass at the Lake Brljan (A) and downstream waters (B) in 2011 and in January 2012; correlation between the phytoplankton biomass and the POC values in the Lake Brljan (C). 
were recorded in the entire water column at the station B2 in November 2011. According to the concentration of specific OM components and fractions determined here, the Lake Brljan and the downstream waters seem to be clean non-eutrophicated water systems. The elevated concentrations of DOC, POC, as well as SAS in the surface waters at the station B in May 2011 could be attributable to phytoplankton production.

\section{Phytoplankton}

The phytoplankton abundance ranged from 5 to $500 \times 10^{5}$ cell $\mathrm{dm}^{-3}$. The phytoplankton biomass at $B$ and $B 2$ stations is shown in Figure $5 A$ and $B$, respectively. The mean biomass ranged from $0.04 \mathrm{mg} \mathrm{dm}^{-3}$ to $1.35 \mathrm{mg} \mathrm{dm}^{-3}$. The phytoplankton study revealed 70 species. Species occurring with the highest biomass were Coelastrum spp., Stephanodiscus hantzschii Grunow, Oscillatoria sp. and Ankyra judayi (G. M. Smith) Fott, while the species with the highest frequency of occurrence were Achnanthidium sp., Lepocinclis spp., Achnanthidium minutissimum (Kützing) Czarnecki and Diatoma vulgaris Bory. The highest phytoplankton biomass at the station $B\left(0.55 \mathrm{mg} \mathrm{dm}^{-3}\right.$, May 2011) and $B 2$ (1.35 mg dm ${ }^{-3}$, November 2011) was coinciding with the highest concentration of SAS, CUCC, DOC and POC. These results support our hypothesis of primary production as a main source of $\mathrm{OM}$. The highest abundance of resuspended benthic algae in the water column at the station B was in June 2011 (53-75\%) and in January $2012(81-92 \%)$ and at B2 in January 2012 (86$99 \%)$. Furthermore, the phytoplankton biomass at the station B correlated significantly with POC $\left(r^{2}=0.62\right.$, Figure $5 \mathrm{C})$, thus suggesting a strong link between phytoplankton biomass and OM present in the water column. OM budget in the Krka River estuary is also under the influence of phytoplankton biomass. ${ }^{[23]}$

\section{CONCLUSION}

Our investigation of OM in the upper reach of the Krka River area was focused on the Lake Brljan and the downstream waters due to possible eutrophication indicated by elevated OM and bottom appearance of RSS in reservoirs. According to the seasonal measurements in the water column conducted in 2011 and in January 2012, no episodes of hypoxic/anoxic conditions were observed during the weak water column stratification (Figure 2). It appears that the influence of the Miljacka HPP was not significant since the highest $\mathrm{OM}$ concentrations coincided with high phytoplankton biomass indicating mainly autochthonous production of OM. Therefore, we could conclude that water in the Lake Brljan and the downstream waters were oligotrophic with seasonal spring and autumn elevated concentrations of SAS, CuCC, DOC and POC. All biogeochemical processes are strongly influenced by the Krka River water regime ${ }^{[26-28]}$ that varies between 10 and $60 \mathrm{~m}^{3} \mathrm{~s}^{-1}$, usually reaching a maximum in winter $\left(>400 \mathrm{~m}^{3} \mathrm{~s}^{-1}\right)$ and minimum in late summer and autumn $\left(<5 \mathrm{~m}^{3} \mathrm{~s}^{-1}\right) \cdot{ }^{[23]}$ The waters in other parts of the Krka River are also classified oligotrophic due to the low concentrations of DOC (under $1 \mathrm{mg} \mathrm{C} \mathrm{dm}^{-3}$ ). ${ }^{[7]}$ The percentage of $\mathrm{POC}$ in total $\mathrm{OM}$ as an additional measure of phytoplankton biomass ranges from 10 to $47 \%$, while this number in a more productive karst lake water systems such as the Lake Visovac (also part of the Krka River) and the Lake Rogoznica (seawater lake located on the Rogoznica peninsula, eastern Adriatic) can be higher, up to 60 and $90 \%{ }^{[26-28]}$ Using simple, fast, non-destructive and relatively cheap voltammetric methods it was possible to reveal quantitative and qualitative properties of $\mathrm{OM}$ components in the lake waters.

Acknowledgment. Financial support of the Krka National Park through the project "Impact of the Miljacka hydroelectric power plant on the Lake Brljan ecosystem" is highly acknowledged. Croatian Science Foundation project IP-2018-01-1717 (MARRES) for unifying of all presented results in this paper is also acknowledged.

\section{List of abbreviations:}

$A C V$ - alternating current voltammetry

CuCC - copper complexing capacity

DOC - dissolved organic carbon

DPASV - differential pulse anodic stripping voltammetry

HPP - hydroelectric power plant

HTCO - high-temperature catalytic oxidation

LSV - linear sweep voltammetry

MCC - metal complexing capacity

NDIR - non-dispersed infrared

OM - organic matter

POC - particulate organic matter

RSD - relative standard deviation

RSS - reduced sulphur species

SAS - surface-active substances

SMDE - static mercury drop electrode

TOC - total organic carbon

\section{REFERENCES}

[1] N. J. Anderson, H. Bennion, A. F. Lotter, Global Change Biol. 2014, 20, 2741.

[2] S. R. Carpenter, N.F. Caraco, D. L. Correll, R. W. Howarth, A. N. Sharpley, V. H. Smith, Ecol. Appl. 1998, 8, 559.

[3] B. Ćosović, I. Ciglenečki, D. Viličić, M. Ahel, Estuarine, Coastal Shelf. Sci. 2000, 51, 705.

[4] D. L. Kirchman, in Processes in Microbial Ecology (Ed. D. L. Kirchman), Oxford University Press, New York, 2012. 
[5] S. R. Carpenter, D. Bolgrien, R. C. Lathrop, C. A. Stow, T. Reed, M. A. Wilson, Aust. J. Ecol. 1998, 23, 68.

[6] S. Emerson, J. Hedges, Chemical oceanography and the marine carbon cycle, 2 ed., Cambridge University Press, New York, 2008, p. 261.

[7] Y. Louis, C. Garnier, V. Lenoble, S. Mounier, N. Cukrov, D. Omanović, I. Pižeta, Mar. Chem. 2009, 114, 110.

[8] S. Strmečki, J. Dautović, M. Plavšić, Environ. Chem. 2014, 11, 158.

[9] M. Plavšić, S. Strmečki, Carbohydr. Polym. 2016, 135, 48.

[10] J. Dautović, V. Vojvodić, N. Tepić, B. Ćosović, I. Ciglenečki, Sci. Total Environ. 2017, 587, 185.

[11] M. Plavšić, S. Strmečki, J. Dautović, V. Vojvodić, G. Olujić, B. Ćosović, Cont. Shelf Res. 2012, 39-40, 41.

[12] M. Plavšić, S. Strmečki, J. Dautović, V. Vojvodić, B. Ćosović, Fresen. Environ. Bull. 2013, 22, 2283.

[13] M. Plavšić, Anal. Lett. 2003, 36, 143.

[14] I. Ciglenečki, Z. Kodba, D. Viličić, B. Ćosović, Croat. Chem. Acta 1998, 71, 217.

[15] M. Plavšić, I. Ciglenečki, S. Strmečki, E. Bura-Nakić, Estuarine, Coastal Shelf Sci. 2011, 92, 277.

[16] D. Finger, M. Schmid, A. Wuest, Water Resour. Res. 2007, 43,

[17] N. Calace, B. M. Petronio, Ann. Chim. 2004, 94, 487.

[18] I. Ciglenečki, B. Ćosović, Mar. Chem. 1996, 52, 87.

[19] E. Bura-Nakić, G.R. Helz, I. Ciglenečki, B. Ćosović, Geochim. Cosmochim. Acta 2009, 73, 3738.
[20] H. Utermöhl, Mitt. int. Ver. theor. angew. Limnol. 1958, 9, 1.

[21] J. W. G. Lund, C. Kipling, E. D. L. Cren, Hydrobiologia 1958, 11, 143.

[22] E. Rott, Schweizerische Zeitschrift für Hydrologie 1981, 43, 34

[23] G. Cauwet, Mar. Chem. 1991, 32, 269.

[24] J. Terzić, T. Marković, J. L. Reberski, Environ. Earth Sci. 2014, 72, 1129.

[25] M. Plavšić, Z. Kwokal, S. Strmečki, Z. Peharec, D. Omanović, M. Branica, Fresenius Environ. Bull. 2009, 18, 327.

[26] I. Ciglenečki, M. Marguš, J. Dautović, E. Bura-Nakić, M. Čanković, V. Hodak Kobasić, M. Ahel, in Vizija i izazovi upravljanja zaštićenim područjima prirode $u$ Republici Hrvatskoj. Aktivna zaštita i održivo upravljanje u Nacionalnom parku "Krka“ (Ed. D. Marguš), Public institution "National Park Krka", Šibenik, 2015, 750.

[27] I. Ciglenečki, E. Bura-Nakić, M. Marguš, J. Dautović, S. Strmečki, M. Plavšić, Utjecaj HE Miljacka na ekosustav jezera Brljan, Ruđer Bošković Institute, Zagreb, 2012, 22.

[28] I. Ciglenečki, M. Ahel, N. Mikac, D. Omanović, N. Vdović, Istraživanje prirodnih značajki i procjena antropogenog utjecaja na kvalitetu ekosustava rijeke Krke u području Visovačkog jezera, Ruđer Bošković Institute, 2015, 94. 